\title{
誤㝶に対するシリコン声帯注射の効果
}

\author{
森 一功・平野 実・藤田真知子・神戸 孝夫
}

\section{Effect of Intrafold Silicone Injection on Aspiration}

\author{
Kazunori Mori, Minoru Hirano, Machiko Fujita and Takao Kanbe \\ (Kurume University)
}

\begin{abstract}
Since 1983 intrafold silicone injection has been performed for unilateral recurrent laryngeal nerve paralysis in our department. It was previously reported that this technique is effective for improving voice. In this study, the effect of this technique on chronic aspiration was retrospectively examined.

One hundred and five patients with chronic aspiration, who had undergone intrafold silicone injection for unilateral vocal fold paralysis, were examined as for the improvement of aspiration. It was found that this technique was effective for aspiration in more than ninty-five per cent of these patients. Therefore intrafold silicone injection should be performed as the first choice for patients with aspiration caused by glottal closure insufficiency. However, this technique was of no effect in patients with large glottal gap and/or impaired mobility of the tongue and larynx. It follows that another method is definitely required for these patients.
\end{abstract}

Key words : aspiration, vocal fold paralysis, intrafold silicone injection

\section{緒言}

一側性声帯麻痺による嗄声, 誤嚥の治療として, 当院 では1983年来，経皮的固化型シリュン注射を行ってきた. 嗄声の改善については既に報告したように良好な成績を 挙げている112)。今回は誤嚥に対する効果を検討した。

燕下第 2 相での誤嚥は主として, 喉頭挙上期型䛊嚥, 喉頭下降期型䛊嚥, 混合型䛊嚥に大別される3) が, 一側 性声帯麻痺では声門閉鎖不全に伴ら喉頭閉鎖の不全によ り喉頭前庭に食塊が流入し, 啹頭下降期に気道内に流入 するのが主たる原因とされている4). それに対して，声 門閉鎖不全を改善するシリュン注入は簡便で有効な手段 であると考えられる3)。 そこで当院では，特に食道など 胸部悪性腫瘍術後の一側性声帯麻痺例で, 筋電図が無反 応な症例や姑息切除例では，可及的早期にシリュン注入 を行い，誤嚥を軽減させて重篤な䛊嚥性肺炎を予防して Quality of Life を向上させてきた ${ }^{5)}$. 本論文では，この
成果を含め, 本法の効果括よび限界を知る目的で以下の 検討を行った。

$$
\text { シリコン注入の方法 }
$$

シリコン注入の方法はすでに詳細に報告している1)2) ので，ここではかいつまんで述べる．まず，喉頭の表面 麻酔の後, アトロピンを筋注する. 喉頭内視鏡によるモ ニターテレビで声帯を明視下に拈いた状態で，輪状甲状 間隙経由で声帯の外側部へと針先を進める。最も膨らま せたい部位に針先が来たかをモ二ターで確認した後, 固 化型シリコン(富士システムズ研究所製, 固化型シリコ ンFX82)を注入する。患者に発声させて声門間隙が葟 ぼ消失し，音声が改善した時点で注入を終える，術後 24 時間の発声を禁じている. 


\section{対象と評価方法}

検討の対象は，1983年から1994年までにシリコン注入 を行った一側性声帯麻痺症例のらち, 誤燕を認めた 105 例である. 誤燕の程度を, 時々水分で誤與し, 固形物で は誤燕しないのを軽症, 固形物・水分で時々誤彉するの を中等度, 常に誤嚥があるのを重症と分類した6).つい で各グループの年齢，罹病期間を調べた．麻痺の原因は， 甲状腺手術などの頸部手術, 甲状腺癌などの頸部疾患, 食道癌手術や肺癌手術などの胸部手術, 食道癌などの胸 部疾患, 挿管性, 中枢性, 不明などのその他, の計 5 群 に分類して調べた。また，術前の最長発声持続時間 (MPT), 楽な発声での平均呼気流率 (MFRc), 基本周波 数変動率 $(\mathrm{PPQ})$, 最大振幅変動率 $(\mathrm{APQ})$, 規格化雑音工 ネルギー (NNEa) を音声検査装置（永島 PS77), 音声評 価装置(リオンSH10)を用いて調べた. 最後に, 注入前 後で誤燕の程度を比較し, 改善の認められない症例に対 してはその原因を検討した。

\section{結果}

注入前には軽症が79例, 中等度が17例, 重症が 9 例で あった. 平均年齢, 䍜病期間は表 1 の如くで, 3 群間に 一定の傾向は認められなかった．麻痺の原因としては， 誤燕が重症の群では胸部の手術が多かった。術前の音声 機能は表 2 で, MPT, MFRc, PPQ, APQ, NNEa すべ て，3群間に有意差は認められなかった。

術前後の比較は表 3 で，シリコン注入の結果，96例 91
表 2 シリコン注入前の音声機能

\begin{tabular}{l|c|c|c}
\hline \hline \multicolumn{1}{c|}{ 程 度 } & 軽 症 & 中等度 & 重 症 \\
\hline MPT (sec) & 4.9 & 3.9 & 4.2 \\
\hline MFRc (ml/sec) & 447 & 539 & 478 \\
\hline PPQ (\%) & 0.94 & 0.83 & 1.11 \\
\hline APQ (\%) & 4.28 & 5.29 & 5.01 \\
\hline NNEa (dB) & -13.6 & -13.6 & -13.5
\end{tabular}

\%で誤燕は消失した。また，誤燕の程度が改善したもの を入れると，100例95\%で有効であった．注入により誤 燕の程度が悪化した例はいない。

本手術により誤燕が改善した症例を示す。

症例は61歳男性で, 胸部食道癌と胃癌に対して右開胸 開腹, 胸部食道, 胃全摘, 胸壁前有茎結腸による再建を らけた。術後, 水分, 固形物で時々誤與し, 誤曣性肺炎 を繰り返すため, 当科を受診した。初診時, 左声帯は副 正中位に固定して括り，喉頭内筋の筋電図では fibrillation で, 自然回復の見込みは少ないと判断し, シリコン 注入を行った. 本症例では透視所見から，主として声門 閉鎖不全による喉頭挙上期型誤燕と考えられた.シリコ ン注入前の食道透視では, 造影剤の気管内への著明な流 入を認める(図 1 )。また，発声時の喉頭ストロボ所見で は声門間隙が認められる(図 2 ).

シリコン注入後の喉頭ストロボ所見では声門間隙は消

表 1 対象と平均年齢, 羅病期間, 麻痺の原因

\begin{tabular}{|c|c|c|c|c|}
\hline \multicolumn{2}{|c|}{ 程 度 } & 軽 & 中 等 度 & 症 \\
\hline \multicolumn{2}{|c|}{ 誤 } & $\begin{array}{l}\text { 水分で時々誤嚥あり } \\
\text { 固形物では誤嚥なし }\end{array}$ & $\begin{array}{l}\text { 水分と固形物とで } \\
\text { 時々誤嚥あり }\end{array}$ & 常に誤嬹あり \\
\hline \multirow{2}{*}{\multicolumn{2}{|c|}{ 症＼cjkstart例＼cjkstart数 }} & 79 & 17 & 9 \\
\hline & & 男性44, 女性35 & 男性 14, 女性 3 & 男性 9 \\
\hline \multicolumn{2}{|c|}{ 平均年 齢 } & 62歳 & 57歳 & 63歳 \\
\hline \multicolumn{2}{|c|}{ 罹 病 期 間 } & 340 日 & 103日 & 179日 \\
\hline \multirow{2}{*}{$\begin{array}{l}\text { 麻 } \\
\text { 痺 }\end{array}$} & 頸部手術 & 20 & 1 & 1 \\
\hline & 頸部疾患 & 6 & 0 & 0 \\
\hline \multirow{2}{*}{$\begin{array}{l}\text { の } \\
\text { 原 }\end{array}$} & 胸部手術 & 29 & 10 & 8 \\
\hline & 胸部疾患 & 11 & 3 & 0 \\
\hline 因 & その他 & 13 & 3 & 0 \\
\hline
\end{tabular}


表 3 シリコン注入前後の誤燕の変化

\begin{tabular}{|c|c|c|c|c|c|c|}
\hline & & \multicolumn{5}{|c|}{ 術 } \\
\hline & & 誤矄なし & 軽 度 & 中等度 & 重 症 & 計 \\
\hline \multirow{2}{*}{ 術 } & 軽 度 & 76 & 3 & 0 & 0 & 79 \\
\hline & 中等度 & 14 & 3 & 0 & 0 & 17 \\
\hline \multirow{2}{*}{ 前 } & 重 症 & 6 & 0 & 1 & 2 & 9 \\
\hline & 計 & 96 & 6 & 1 & 2 & 105 \\
\hline
\end{tabular}

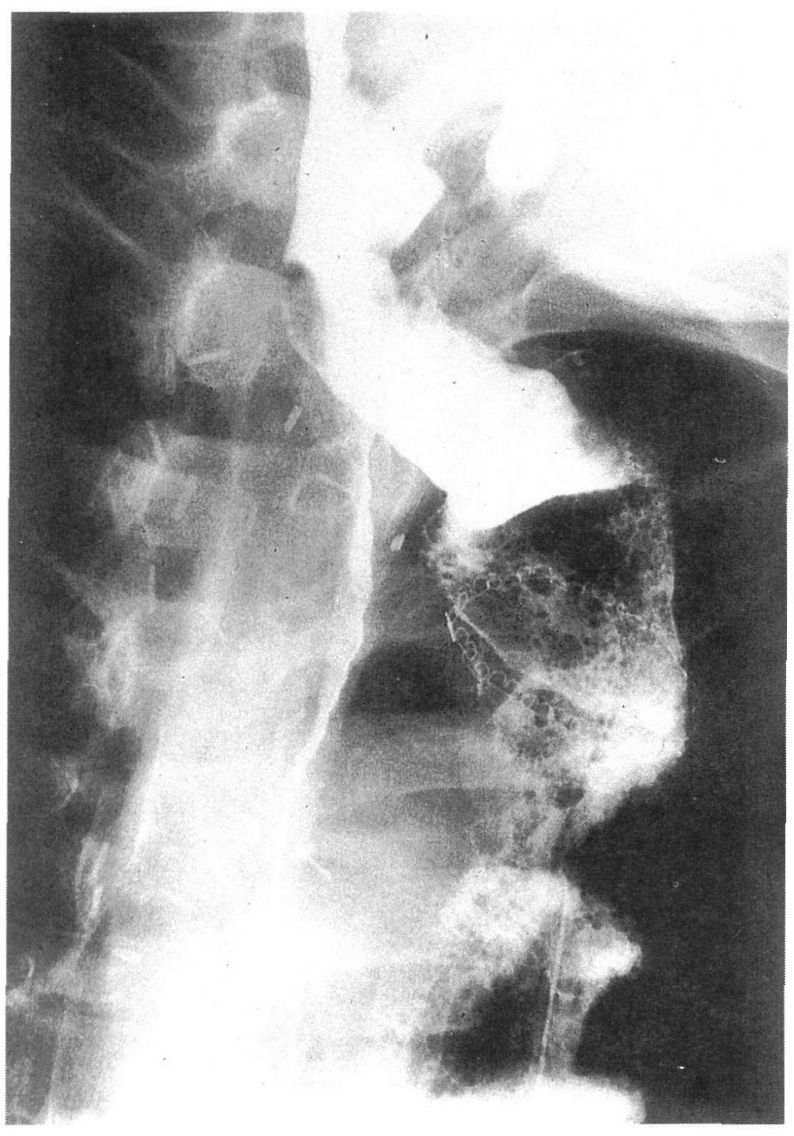

図 1 シリコン注入前の食道透視

失し(図 3)，また食道透視所見では誤燕はなくなった(図 4 ). 以後，経口摂取を行い，順調に回復した。

次に, シリコン注入後も䛊嚥が残った症例について検 討与る (表 4). 術前軽度, 術後も軽症の 3 例の5 症例 1 は口腔内癌のために舌を全摘して和り，嚥下第 1 相で の障害が著明であった。症例 2 は声帯萎縮がつよく、シ リコン注入後も声門間隙が残った。症例 3 は声帯の上下

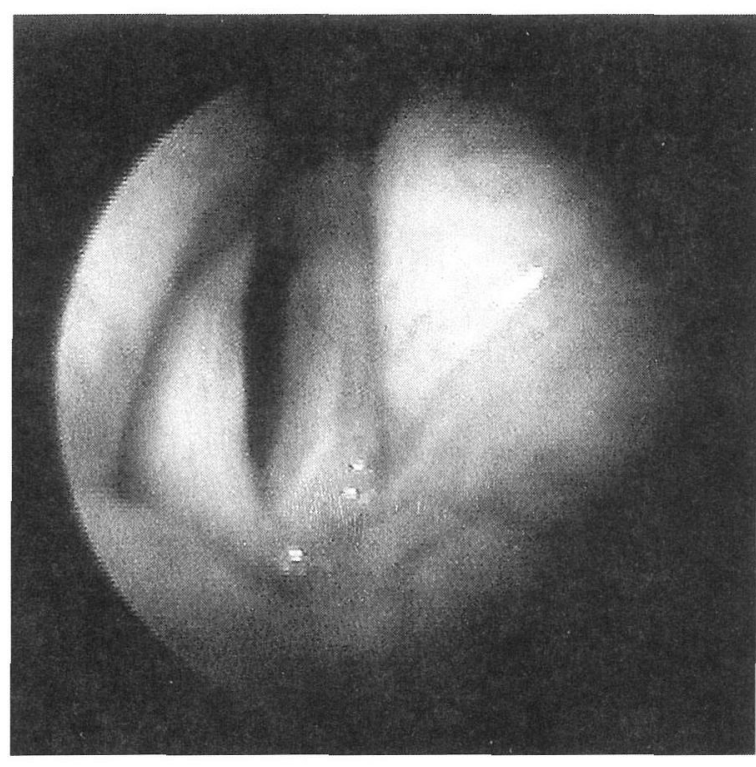

図 2 シリコン注入前の喉頭ストロボ所見

でのレベル差が大きく, 声門後方の大きな声門間隙がン リコン注入により改善しなかった。術前中等度で, 術後 軽症となった症例の内, 症例 4 は喉頭蓋の形態異常があ つて披裂喉頭蓋ヒダの締まりが悪く，喉頭挙上期に誤嶼 を認めた。症例 5 は声帯が中間位固定で注入後も声門間 隙が残り, 症例 6 は副正中位固定だが声帯萎縮が強く, やはり声門間隙が注入後も残った。. 症例 7 は術前重症, 術後中等度であるが，声門間陌が残った上に，気管切開 のために喉頭が全く挙上しなかった。症例 8,9 はシリ コン注入が全く無効であった例で, 症例 8 は迷走神経, 舌下神経を切断して就り，鱟下反射が全く認められなか らた。症例 9 は脳梗塞の既往があり、與下第 1 期での舌 の送り込みが悪く, また食道癌術後で喉頭挙上が著明に 障害されていた。 


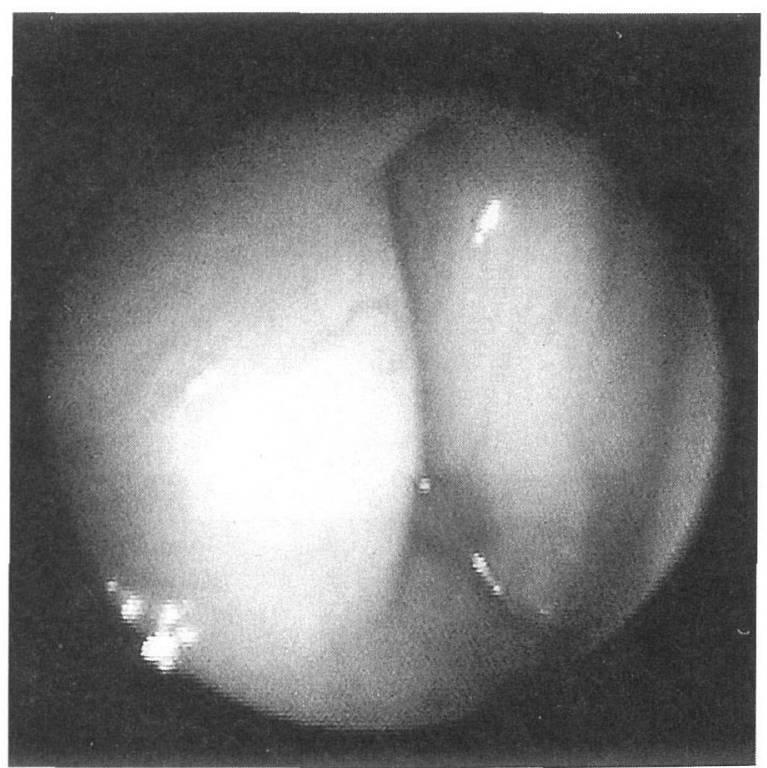

図 3 シリコン注入後の㬋頭ストロボ所見

\section{考按}

反回神経麻痺では発声時に声門閉鎖不全が見られても 誤嚥のない例はよく経験するところであり，声門閉鎖不 全のみが䛊嚥の原因とは考劣られず，知覚障害による防 御反射の障害が䛊嚥を助長しているものと考えられ る7)8、。た，䛊與を恐れて十分な嚥下活動を行わず， そのために喉頭挙上が不十分になるといら考光もある9 結局，臨床的に反回神経麻疾で声門閉鎖不全に伴う誤與 が比較的少ないのは喉頭周曲の神経筋の共同作用により 補助的に声門閉鎖を助けているからと考光られている10).

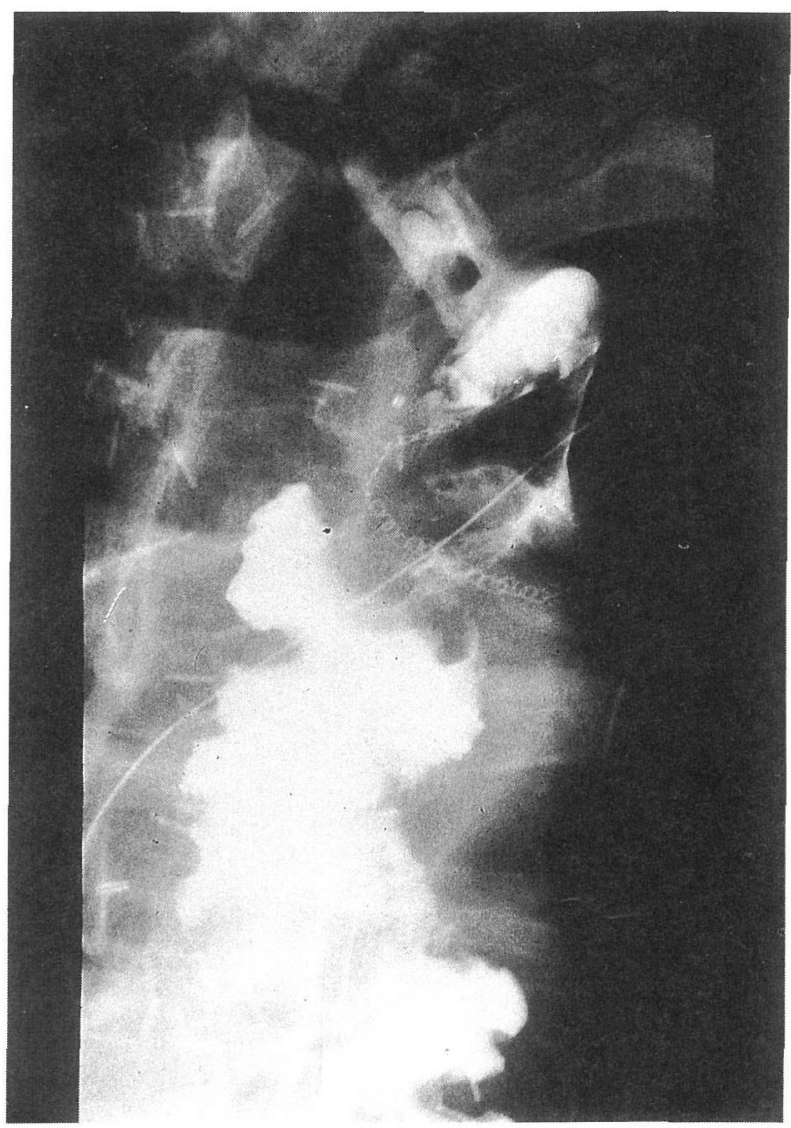

図 4 シリコン注入後の食道透視

今回の検討で誤嚥の程度を 3 段階に分類したところ， 常に誤嚥がある重症例が 9 例認められた。そこでこれら 3 群を比較すると，平均年齢，罹病期間で，3 群間に有

表 4 誤莜の消失しなかった症例

\begin{tabular}{c|c|c|c|c|l|l}
\hline \hline 症例 & 術前 & 術後 & 年齡 & 性 & \multicolumn{1}{|c|}{ 麻疩の原因 } & \multicolumn{1}{|c}{ 理 } \\
\hline 1 & 軽症 & 軽症 & 69 & 男 & 食道癌 & 舌亜全摘 \\
\hline 2 & 軽症 & 軽症 & 77 & 男 & 肺癌 & 声門間隙残る \\
\hline 3 & 軽症 & 軽症 & 57 & 女 & 甲状腺手術 & 声門間隙残る \\
\hline 4 & 中等度 & 軽症 & 67 & 男 & 肺手術 & 喉頭蓋の形態異常 \\
\hline 5 & 中等度 & 軽症 & 70 & 男 & 肺癌 & 声門間隙残る \\
\hline 6 & 中等度 & 軽症 & 46 & 男 & 肺癌 & 声門間隙残る \\
\hline 7 & 重症 & 中等度 & 66 & 男 & 食道手術 & 喉頭挙上しない \\
\hline 8 & 重症 & 重症 & 60 & 男 & 頸部神経鞘腫手術 & 嚥下反射なし \\
\hline 9 & 重症 & 重症 & 81 & 男 & 食道手術 & 脳梗塞
\end{tabular}


意差は認められず，また，声門閉鎖不全の程度をある程 度反映する音声機能(特に MPT, MFRc, NNEa)でも， 3 群間に有意差は認められなかった。ただ誤嚥が重症の 群では，麻痺の原因としては胸部の手術が多かった．例 えば食道癌術後の誤嚥の原因としては，頸部食道吻合後 の㓔痕による喉頭挙上の障害, 反回神経麻痺による声門 閉鎖不全による喉頭挙上期型䛊嬹, 頸部食道の屈曲や吻 合部による食道内圧の上昇などによる喉頭下降期型誤嚥, 食道切除による嚥下第 3 期型誤嚥が混在しているとされ る11). 胸部の手術に起因する重症誤嚥の原因は，声門閉 鎖不全のみではなくこれらの要因が絡み合っている可能 性が大きいと考えられる，このことを反映してか，シリ コン注入により誤嚥が消失するのは軽度群では96\%であ ったが，重症群では67\%にとどまった。消失しない例の 解析では, 術前の声門間隙が大きすぎてシリコンのみで は声門間隙が消失しなかった例が 4 例有り，これらは披 裂軟骨内転術の適応ではなかったかと反省される。また， 嚥下第 1 相での舌運動の不良例や，喉頭挙上の著明な障 害例でも䛊燕は消失していない。これらはシリコンだけ では不十分で，その他の方策が必要と考えられた。すな わち, 声門間隙の大きいものや声門閉鎖不全以外の原因 を伴ら誤嚥には，他の治療法が必要であることが再確認 された。

喉頭挙上期型誤嚥に対する治療法としては種々報告さ れている344)が, なかでも, シリコン注入術の利点とし ては, 簡単で安全であり，外来手術としても行える点が 挙げられる。また, 重篤な副作用は 1 例もなく, 安全性 が確認されている2). そして誤嚥に対して全体として95 \%で有効であった．一方，シリコン注入により声門閉鎖 圧は有意に上昇し，聴下にも有効であることは実験的に も示されている12).それゆえ，シリコン注入は声門閉鎖 不全に伴う誤燕, 特に軽度䛊嚥には簡便かつ有効な手段 であり，第一選択として施行してみる価值があると考え られる。

\section{まとめ}

1 ）シリコン注入の誤嚥に対する効果を調べたところ, 95\%で効果を認めた.

2 ）それゆえ，シリコン注入は声門閉鎖不全に伴ら諡
曣には簡便かつ有効な手段であり，第一選択として施行 してみる価值があるが，声門間隙の大きいものやそれ以 外の原因を伴ら䛊與には，他の治療法が必要である.

本論文の要旨は第46回日本気管食道科学会(宇都宮)で口演し た.

\section{参考文献}

1) Hirano M, Tanaka S, Tanaka Y, et al : Transcutaneous intrafold injection for unilateral vocal fold paralysis ; functional results. Ann Otol Rhinol Laryngol $99: 598 \sim 604$, 1990.

2 ) 森 一功, 藤田真知子, 平野 実: 一側性声帯麻痺に対す る経皮的固化型シリコン声帯注射. 耳鼻臨床 88 : 984 986, 1995.

3 ) 平野 実, 進 武幹, 吉田義一, 他 : 誤嚥の臨床的分類と その意義 一主として燕下の動的障害について一. 日気食 会報 31：285〜290, 1980 .

4 ）丘村 熙: 嚥下のしくみと臨床. 101〜102頁, 金原出版, 1992.

5 ) 藤田真知子, 平野 実, 藤田博正, 他: 食道癌術後の反回 神経麻㽻. 日気食会報 $39: 444 \sim 449,1988$.

6 ）黑岩泰直：口腔および中咽頭癌術後の燕下機能.耳鼻 38 : $812 \sim 824,1992$.

7 ）進 武幹, 前山忠嗣, 森川郁郎, 他 : 反回神経麻痺に打け る誤燕. 耳鼻 $31:$ 416 420, 1985.

8 ）森川郁郎：誤曣のメカニズムに関する基礎的研究一主と して反回神経麻痺の関与について一. 耳鼻 31:315〜329, 1985.

9 ）村上 泰 : 嚥下第二相障害の病態生理と治療. 日気食会報 $27: 362 \sim 366,1976$.

10）進 武幹 : 嚥下時の喉頭閉鎖. 日気食会報 $26: 131 \sim 142$, 1975.

11）藤田博正, 末吉 晋, 入江 均, 他 : 胸部食道癌切除後の 反回神経麻痺・嚥下性肺炎とその対策. 日気食会報 43 : 446 456, 1992.

12）渡邊 宏, 岩永康成, 梅崎俊郎: 声門閉鎖に関する実験的 研究. 喉頭 $3: 88 \sim 92,1991$.

/原稿受付 : 平成 7 年 7 月 28 日 原稿採択 : 平成 7 年 8 月 30 日

別刷請求先 : 森 一功

厂 830 久留米市旭町 67

久留米大学医学部耳鼻咽喉科学教室 